\title{
Perceived Corporate Politics and Political Behavior: Cause or Effect for Each Other
}

\author{
Ganesh Bhattarai \\ ganesh@ncc.edu.np \\ Lecturer, Nepal Commerce Campus, T.U.
}

\begin{abstract}
In the literature of corporate politics, directionality (cause or effect) of the relationship between perceived corporate politics and political behavior is unsettled. This study was carried out to measure the association between employee's perceived corporate politics and their political behavior as a response to such context. Positivist research philosophy, deductive reasoning approach of research, and inferential statistic were adopted to infer the conclusion. Perceptual cross-sectional data were taken from the employees working in the Nepalese Banking industry. Structural Equation Modeling, using Analysis of Momentum Structure, was adopted to calculate the results. Data analysis of 725 respondents revealed that employees' perceived corporate politics positively affected their political behavior regarding self-promotion and ingratiation. Moreover, this study measured that employees' self-promoting behavior causes to predict their ingratiating behavior at the workplace. Practical implications, theoretical implications, and direction for further study are recommended.
\end{abstract}

Keywords: Ingratiation, perceived corporate politics, political behavior, organizational politics, self-promotion

\section{Introduction}

Politics at the workplace are unavoidable, and many studies are devoted to corporate politics, especially in developed countries' work settings. Among them, perception of corporate politics, employees' political skills, and political behaviors are the study's common subject matter. In the literature of corporate politics, antecedents and outcomes of perceived corporate politics and political behavior are mostly studied. But interrelationship between employees' perceived corporate politics and their political behavior is not settled. Studies are not streamlined to solve this somehow tricky issue. Even constructs corporate politics, political behavior, and political perception are used interchangeably (e.g., Gandz \& Murray, 1980; Mayes \& Allen, 1977; Mintzberg, 1983; Pfeffer, 1981). However, this study assumes that perception of corporate politics and political behavior are closely related but different constructs. Political behaviors are actor's covert or overt actions to achieve targets. Still, the perception of politics is the subjective state of the actors that are formed from own or other's political behavior or actions in the workplace.

Moreover, the directionality of the relationship between employees' political behavior and their perceived politics is controversial. Empirical evidence and theoretical argument of Ferris et al. (2000), Harrell-Cook (1999), Valle (1997), and Valle and Perrewe (2000) established that employees' perceived corporate politics affects their political behavior. But Hill et al. (2016) and Vigoda and Cohen (2002) have tested the opposite relationship that employees' political behaviors cause to perception of politics from their workplace. Level and source of politics might determine political behavior and political perception as 
cause or effect for each other (Hill et al., 2016).

Political behavior and perceptions of corporate politics are distinct constructs that are reciprocally related (Leslie \& Gelfand, 2012). Specifically, high levels of perceptions of corporate politics increase the tendency to engage in political behavior, reinforcing perceptions of corporate politics (Ferris et al., 2000). The interrelationship between political behavior and corporate politics perceptions suggests that they have similar nomological networks (Leslie \& Gelfand, 2012). Political behavior and perception of politics can be both cause and effect for each other; if the employees have perceived their workplace as political, and then they may exhibit their political behavior to cope up the context; and, if other people are exhibiting political behavior, then someone may perceive their workplace is political.

As a response to the aforementioned unsettled issue about the directional relationship of the perceived corporate politics and political behavior, this study targeted to measure the impact of perceived corporate politics on their political behaviors in terms of self-promoting behavior and ingratiating behavior. This study has adopted the individual level of political behavior and perceived politics to address these issues.

\section{Review of Literature}

\section{Perception of Corporate Politics}

Ferris et al. (1989) and Ferris et al. (2002) have identified three characteristics of perception of corporate politics that serve to integrate this construct with a broader work stress literature (Perrewe et al. 2000). Firstly, experienced individual phenomenon: perception of corporate politics has been conceptualized as an individually experienced phenomenon rather than a specific feature of the work environment, as events, people, and activities are perceived and interpreted differently by different people (Perrewe et al., 2000). Therefore, how the employee perceives and responds to corporate politics' perception depends on the beholder's eye (Harris \& Kacmar, 2005). For example, the company's promotion decision can be perceived as political by one unsuccessful competitor, and the same event can be perceived as rational by another successful competitor. Secondly, uncertainty and ambiguity: uncertainty and ambiguity are central to understanding processes and outcomes associated with the perception of corporate politics (Ferris et al., 1996). For example, vague promotion criteria may lead to uncertainty and ambiguity among competitors to pursue their promotion. As a result, the employee may engage in self-serving biases to make a favorable decision for themselves. Finally, threat or opportunities: perception of corporate politics can be interpreted as either a threat or opportunity (Perrewe et al., 2000). For example, employees who feel that they have a high degree of understanding and control over the political process are likely to view corporate politics as an opportunity to get ahead. In contrast, employees who have less understanding and control tend to view corporate politics as more threatening (Perrewe et al., 2000).

\section{Political Behaviors}

Political behavior refers to intentional acts (Allen et al., 1979) from a broad repertoire that may include influence tactics, self-presentation, impression management, voice, and helping behavior to manage (create, maintain, modify, or abandon) the shared meanings of organizational situations to produce desired outcomes that would otherwise be unfeasible (Ferris \& Treadway, 2012). According to Valle and Perrewe (2000), individual political behavior is the exercise of a tactical influence of the individual, which is strategically goal-directed, rational, conscious, and intended to promote self-interest, either at the expense of or in support of others' interest. These tactics may not require as part of one's organizational role, but that influence, or attempt to influence, the distribution of advantages and disadvantages within the organization (Farrell \& Petersen, 1982).

Political behavior is a broad term that can encompass behavior enacted by the self, behavior enacted by others, and behaviors of the group or organization (Hill et al., 2016, p. 391). However, this study has considered political behavior as the behavior enacted by the individual political perceiver, which means 
individuals perceive their work environment as political and exhibit specific behavior to cope with the environment. Terminologies influence tactics, political tactics, influence behavior, and political behavior are often used interchangeably, and all these describe the use of power to change others' behavior (Landells \& Albrecht, 2016).

Political behavior describes a set of behaviors that can be used to exert influence in the pursuit of one's interests, which may or may not be sanctioned by the organization and may or may not benefit the organization. While enacting political behaviors to attain preferred outcomes, actors are also attempting to hide the self-serving aspect of their motivations as an effort to reduce the resistance of others to influence attempts (Ferris et al., 2000). Consciously or unconsciously, political actors keep their motivation of political behavior covert because of the well-established negative conceptualization of consequences of perceived politics at the workplace (Hill et al., 2016).

\section{Perceived Corporate Politics and Political Behaviour}

Ferris et al. (1989) have suggested that there are at least three potential responses to perceptions of a politically charged organizational environment: either employees (1) may withdraw from the organization, or (2) they may remain as a member of the organization, but not become involved in the politics, or (3) they may stay with the organization and attempt to engage themselves in the political activity. The first response is possible when there are widespread opportunities for an alternative job, but it is not easy to get an alternative job by everyone. Moreover, direct and indirect costs are associated with withdrawal from the current job or organization. Therefore, very few employees choose this alternative. The second response is also not possible for a long time because people, by nature, cannot stay a long time, keeping themselves isolated from the culture where they are. In the long run, they have to adjust themselves to the prevailing work culture, which means they should be engaged in political activities. Hence, mostly, the third response happens in the real work environment.

Those who decide to stay and engage in politics may exert an effort to gain some degree of understanding and control through their political behaviors (e.g., ingratiation and self-promotion) over the organizational environment. Organizational members engage in various behaviors, including political behavior or influence tactics, to restore or maintain their sense of personal control over their organizational environments (Dulebohn, 1997). The effect of corporate politics on employee outcomes could be improved if the employees exercise or exhibit their political behaviors. It is human nature that people try to survive developing proper capacity, skills, tactics, and behaviors for the particular environment because economic, psychological, and social pains are associated with withdrawal from the job. A political environment promotes managers to develop better political capabilities that effectively handle complex issues between organizations (Wayne \& Ferris, 1990). Therefore, employees' perception of their working environment as political leads to developing political behaviors to tackle the perceived environment. Hence, this study purposes the following hypothesis.

Hypothesis 1: Employees' perceived corporate politics cause them to exhibit their self-promotion behavior. Moreover, there is a positive effect of employees' perceived corporate politics on their self-promoting behavior.

Hypothesis 2: Employees perceived corporate politics cause them to exhibit their ingratiation behavior. Moreover, there is a positive effect of employees' perceived corporate politics on their ingratiation.

\section{Method}

\section{Level of Analysis}

Issues of analysis level serve as a constraint incorporate politics studies (Dipboye \& Foster, 2002). Corporate politics may be both experienced and enacted differently at the individual, group, and 


\section{Issue 1 May/June 2020}

organizational levels (Hill et al., 2016). Measurement of socially constructed phenomena like political behavior is problematic because they occur in constantly shifting realities due to the individuals' contextspecific actions (Sederberg, 1984). Therefore, social science researchers' challenge is to identify the proper level of analyses of both the phenomena and the useful data source for measuring such phenomena under these conditions of "shifting realities" (Ferris et al., 2002). Most corporate politics research and theory suggest that each level represents a different construct. Individual perceptions of politics, group perceptions of politics, and corporate politics are different constructs with distinct attributes and effects (Ferris et al., 2002). Maslyn and Fedor (1998) have verified that individuals experience and distinguish between politics occurring at the group and corporate level. These differences in perceptions across levels lead to different subsequent behaviors.

To avoid the research fallacies (e.g., ecological fallacy, exceptional fallacy) and subsequent inferential errors, level of analysis has been identified as an essential consideration whenever phenomena of interest are thought to occur at more than one level. A construct can be developed from the influences of either one or multiple levels of phenomena, and a developed construct may impact more than one level differently. Therefore, proper matching between analysis levels is a fundamental requirement to develop or refine corporate politics theory. Hill et al. (2016) state actual or objectives corporate politics is quite relevant at the group level phenomena, and perceptual or subjective politics is quite relevant at the individual level of phenomena. Hence, considering the notion that individual level of perception of corporate politics will have different effects at the individual, dyadic, group, and organizational levels. This study has examined the associations of the individual level of constructs (i.e., perception of corporate politics and political behaviors)

\section{Measure}

Perceived corporate politics was measured by nine items scale. Out of the nine items, six items were adopted from the Kacmar and Ferris (1991), and the remaining three items were adopted from the Hochwarter et al. (2003). Few sample items of the perceived corporate politics include: (a) there are groups of people in my organization who always get in things their way because no one wants to challenge them; (b) here people are more concentrated to please senior or influential people who can help them. Political behaviors (i.e., self-promotion and ingratiation) were measured by 14 items (seven items for self-promotion and seven items for ingratiation). Out of the 14 items, five items for self-promotion and five items for ingratiation were adopted from Bolino and Turnley (1999). In addition to Bolino and Turnley's scale, two items for self-promotion and two items for ingratiation were added to have better content validity in our context. Sample items of political behavior include: (1) I make people aware of my talents and qualification (self-promotion), and (2) I do praise my colleagues for their accomplishments so that they will consider me a nice person (ingratiation). All the items of the measures of this study were measured in five-point Likerttype scales. Respondents were asked to rate each statement strongly disagreed (1) to strongly agreed (5).

\section{Sampling and Questionnaire Administration}

Respondents of the study were taken from the employees working in Nepalese commercial banks. Using the non-random sampling method, eleven hundred ninety-nine questionnaires were distributed within the selected seventeen commercial banks as per the researcher's convenience. At the researcher's request, one referent person was assigned by each bank for the facilitation of the survey process within their concerned bank. Nine hundred twenty-seven (77 \%) questionnaires were filled up and returned. However, eight hundred seventy-three (73\%) questionnaires were found ready to use for the study purposes. Finally, seven hundred twenty-five ( $83 \%$ of the proper respondents) questionnaires were analyzed after ensuring the fit-index's goodness. 


\section{Confirmatory Factor Analysis and Structural Equation Model}

To ensure the goodness of fit-index, confirmatory factor analysis was employed using Analysis of Momentum Structure (AMOS) Version 24. All the items (23 items) were loaded in the three respective. After the modification indices, four pairs of error terms within the respective latent construct showed the covariance error term more than .30 (Awang, 2015) were correlated to set as a free parameter estimate. Consequently, a useful model fit index was achieved as per the criteria recommended by Gaskin and Lim (2016), as shown in Table 1.

Table 1

Measurement Model Fit Measures

\begin{tabular}{lccc}
\hline Measure & Estimate & Threshold for excellent model & Interpretation \\
\hline CMIN & 574.508 & NA & NA \\
DF & 181 & NA & NA \\
CMIN/DF & 3.174 & Between 1 and 3 & Acceptable \\
CFI & 0.963 & $>0.95$ & Excellent \\
SRMR & 0.044 & $<0.08$ & Excellent \\
RMSEA & 0.055 & $<0.06$ & Excellent \\
PClose & 0.057 & $>0.05$ & Excellent \\
\hline
\end{tabular}

Combination of measures, then absolute one, has recommended having the goodness of fit-index (Hu \& Bentler, 1999) and recommended preferable combinations were the Comparative Fit Index (CFI), Standardized Root Mean Square Residual (SRMR), and Root Mean Square Error of Approximation (RMSEA) (Gaskin \& Lim, 2016).

\section{Reliability and Validity}

Composite reliability is adopted in Structural Equation Modeling analysis as its value is usually higher than Cronbach Alpha, in which the difference is insignificant (Peterson \& Kim, 2013). To ensure the reliability of the measures, measures have to guarantee either internal reliability $\geq .70$ or composite reliability $(C R) \geq .60$, or Average variance extracted (AVE) $\geq .50$ (Awang, 2015). Moreover, Hair et al. (2010) have stated the composite reliability should be $\geq .70$ to ensure the measure's reliability. As depicted in Table 3, in this study, for each latent construct, both Cronbach Alpha and Composite Reliability were higher than .70. AVE was higher than .50 for each construct. Therefore, each measure used in this study ensures the reliability of the measure.

Table 3

Reliability and Validity Analysis

\begin{tabular}{lccccc}
\hline & CR & AVE & MSV & Cronbach's alpha $(\alpha)$ & Square root of AVE \\
\hline Perception of corporate politics & 0.934 & 0.613 & 0.179 & 0.937 & 0.783 \\
Self-promotion & 0.913 & 0.638 & 0.311 & 0.927 & 0.799 \\
Ingratiation & 0.899 & 0.599 & 0.311 & 0.9 & 0.774 \\
\hline
\end{tabular}

If there is an issue of convergent validity, the latent factor is not well explained by its observed variables. This validity is achieved when all items in a measurement model are statistically significant (Awang, 2015) and Average Variance Extraction (AVE) for every latent construct is greater than .50 (Awang, 2015; Hair et al., 2010). Likewise, Malhotra and Dash (2011) have noted that AVE is a more conservative measure than $\mathrm{CR}$; therefore, based on $\mathrm{CR}$ alone, the researcher may conclude that the construct's convergent validity is adequate (Malhotra \& Dash, 2011). As depicted in Table 3, the AVE for all latent constructs was 
greater than .50. This means all the measures used in this study lead to ensure the convergent validity of the inferences.

Discriminant validity of the measures is ensured when Maximum Shared Variance (MSV) is less than AVE (Hair et al., 2010), or the square root of AVE is higher than the inter-construct correlation of the corresponding factor (Gaskin \& Lim, 2016). As depicted in Table 3, MSV is less than AVE in every case. As shown in Table 3 square root of every AVE is higher than their corresponding inter-construct correlation. Hence, this study ensured the discriminant validity of the constructs.

\section{Results}

In the next step, after satisfying the measurement model, a path was drawn specifying the hypothesized model. The hypothesized model was the impact of perceived corporate politics on employees' selfpromoting behavior and ingratiating behavior. But the hypothesized model could not satisfy the acceptable goodness of fit model (Awang, 2015; Gaskin \& Lim, 2016), as shown in Table 2. To improve the path model fit index, a causal path was drawn specifying the impact of employees' self-promotion behavior on their ingratiation behavior. Consequently, added path (self-promotion to ingratiation behavior) contributed to improve the fitness of the model. Hence, the revised model, shown in Table 2, produced the acceptable path model fit index satisfying the required criteria of Awang (2015) and Gaskin and Lim (2016).

Table 2

Path Model fit measure

\begin{tabular}{lccccc}
\hline \multirow{2}{*}{ Measure } & Threshold for the & \multicolumn{2}{c}{ Hypothesized Model } & \multicolumn{2}{c}{ Revised Model } \\
\cline { 3 - 6 } & excellent model & Estimate & Interpretation & Estimate & Interpretation \\
\hline CMIN & NA & 748.007 & NA & 574.508 & NA \\
DF & NA & 182 & NA & 181 & NA \\
CMIN/DF & Between 1 and 3 & 4.11 & Acceptable & 3.174 & Acceptable \\
CFI & $>0.95$ & 0.946 & Acceptable & 0.963 & Excellent \\
SRMR & $<0.08$ & 0.125 & Terrible & 0.044 & Excellent \\
RMSEA & $<0.06$ & 0.066 & Acceptable & 0.055 & Excellent \\
PClose & $>0.05$ & 0 & Not Estimated & 0.057 & Excellent \\
\hline
\end{tabular}

A revised path model is presented in figure 1, which is used to decide the hypothesized relationship. As shown in the path model in figure 1, the coefficient of perceived corporate politics to predict employees' political behavior in terms of self-promotion was positive and statistically significant $(\mathrm{B}=.18, \mathrm{p}<.001)$. This coefficient indicated that there was a positive effect of employees' perceived corporate politics on selfpromoting behavior. Hence, Hypothesis 1 is supported.

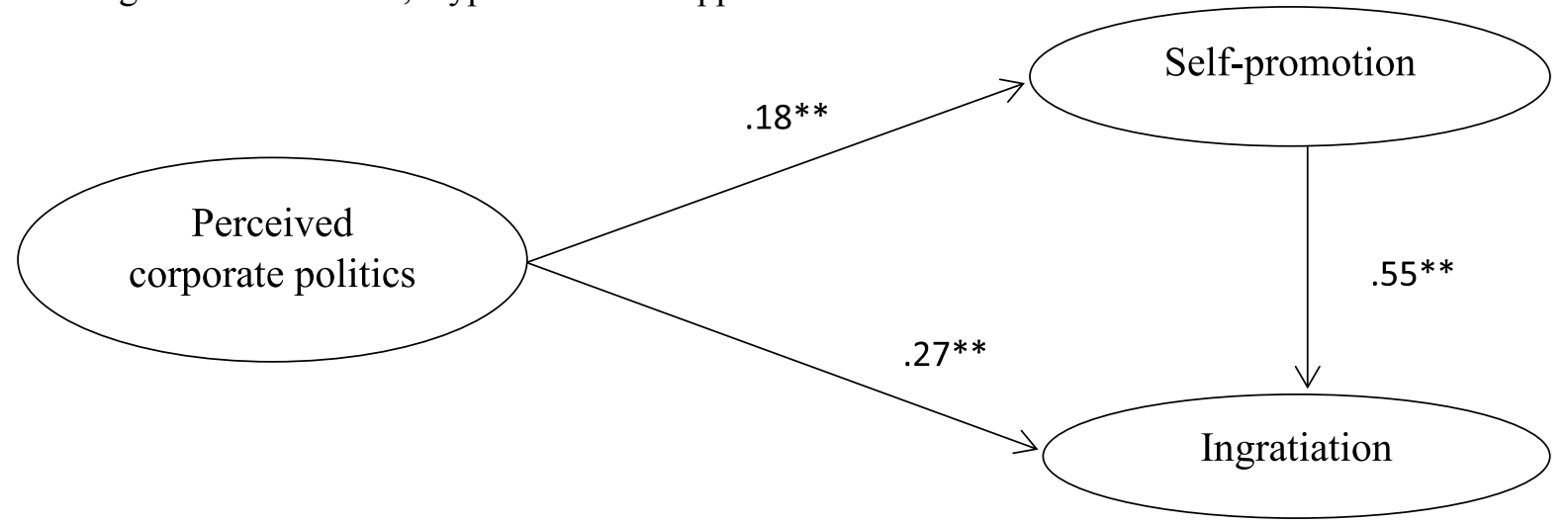

Figure 1: Impact of perceived corporate politics on political behaviour (i.e., self-promotion and ingratiation and self-promotion) 
Likewise, figure 1 depicted that the coefficient of perceived corporate politics to predict political behavior in terms of ingratiation was positive and statistically significant $(\mathrm{B}=.27, \mathrm{p}<.001)$. This coefficient denoted the positive impact of perceived corporate politics on their ingratiating behavior. Therefore, Hypothesis 2 is supported. Besides the hypothesized relationship, to ensure path model fit, this study has added a path showing the effect of employees' self-promoting behavior on their ingratiating behavior, which was positive and statistically significant $(\mathrm{B}=.55, \mathrm{p}<.001)$.

\section{Discussion}

This study revealed that employees' perceived corporate politics positively predicts their political behaviors regarding self-promoting and ingratiating behavior. It indicates whenever employees perceive their workplace as political; they tend to exhibit and exercise their political behavior. If employees do not feel politics in their workplace, they do not necessarily involve themselves in politics and exhibit less political behaviors (self-promotion and ingratiation). The results of this study consist of several prior studies like Ferris et al. (2000), Harrell-Cook (1999), Valle (1997), and Valle and Perrewe (2000). However, the results contradict Hill et al. (2016), who have tested the opposite association between the perceived corporate politics and political behavior. Likewise, Vigoda and Cohen (2002) have found that individuals who successfully engaged in political behavior also had less negative corporate politics perceptions.

Plausible causes for such contradicting findings can be the level of politics (i.e., individual level, group level, and organizational level), because of the politics' (i.e., where politics is originated and practiced) level, its effect might be different. Another possible cause might be the person whose political behaviour is considered (either respondent's own political behaviour or other's political behaviour). Self-enacted political behavior may be a response to politics perception. People may perceive politics because they observe themselves behaving politically (Hill et al., 2016). It is expected that the behavior one exhibits will affect one's perception, and similarly, one's perception will affect one's behavior. Researchers have underscored the distinction between the individual's political behaviors and individual's perception of politics. But they have focused their attention on behavior enacted by the perceiver than actual political behavior (Hill et al., 2016). It is because the working environment creates individual's perception of politics and individual reacts based on their internalized perception.

Fedor and Maslyn (2002) state the need for disentanglement of the relationship between political behavior and political perception. Still, Hill et al. (2016) highlight to gain clarity on exactly how politics perception and political behavior are entangled. Hill et al. have tested that perception of corporate politics and political behavior is distinctly constructed, but related, effects of political behavior on outcomes are best modeled indirectly through perception. Ferris et al. (2002) state that systematic investigation in corporate politics has fallen into one of two categories until their review. The first area is related to the nature of actual political behavior, influence tactics and influence strategies, and their consequences. The second area is related to perceptions of politics in work environments by individual employees, the antecedents of such perceptions, and their consequences. Therefore, corporate politics' perception needs to be differentiated from agreed political behaviors (Vigoda, 2003).

There is sparse research study regarding the relationship between perception of corporate politics and political behavior (Hill et al., 2016). When an experimental examination of the perception of corporate politics and political behavior is carried out concurrently, political behavior has been conceptualized as the behavior the individual has enacted (Hill et al., 2016) and has subsequently been examined in different arrangements. For example, political behaviors have tested as moderator by Harrelell-Cook et al. (1999) and Valle and Perrewe (2000), as a mediator by Ferris et al. (2000), as the outcomes by Fandt and Ferris (1990) and Valle (1997), and as a predictor for the perception of corporate politics by Hill et al. (2016).

In addition to hypothesized relationship, this study tested the positive impact $(\mathrm{B}=.55, \mathrm{p}<.001)$ of employees' self-promoting behavior on their ingratiating behavior to get the proper path model fit index. It directed that an increase in employees' self-promotion behavior contributes to an increase in their 
ingratiation behavior. Both political behaviors move in the same direction. Ferris et al. (1989) argued that employees who stayed in the politically active environment make themselves engage to survive and enjoy the environment. Hence, it is natural to exercise political behavior through self-promotion and ingratiation. However, this relationship requires further testing to have generalizability.

\section{Implications}

This study tested the positive association between employees' perceived corporate politics and their political behavior (i.e., self-promotion and ingratiation). As a source of employees' political behavior was their perception of politics at the workplace, the manager may intervene to minimize perceived corporate politics to minimize political behavior. Managers may intervene in the source of perceived politics, such as minimizing workplace injustice, making employees participate in decision making, minimizing ambiguity, ensuring transparency, making fairness in reward and punishment, etc. Likewise, theoretically, in the unclear theoretical association of perceived corporate politics and political behavior, this study's findings present evidence for further academic work to generalize the theory regarding the cause and effect relationship between politics perception and political behavior with each other. Likewise, this study measured the positive effect of self-promoting behavior on ingratiating behavior as the requirement for a good path model fit index. This result invites further investigation for its generalization with theoretical backup.

\section{Conclusion}

Employees' perceived corporate politics positively impacts their political behavior regarding their self-promoting behavior and ingratiating behavior. Employees' perception of their workplace as political is the source of their political behavior. Moreover, an increase in employees' self-promoting political behavior causes an increase in their ingratiating political behavior.

\section{References}

Allen, R. W., Madison, D. L., Porter, L. W., Renwick, P. A., \& Mayes, B. T. (1979). Organizational politics: Tactics and characteristics of its actors. California Management Review, 22(1), 77-83. https://doi. org/10.2307\%2F41164852

Awang, Z. (2015). SEM made simple: A gentle approach to learning structural equation modeling. Bandar Baru Bangi, MPWS Rich Resources.

Dipboye, R. L., \& Foster, J. B. (2002), Multi-level theorizing about perceptions of organizational politics, in Francis J. Yammarino, Fred Dansereau (eds), The Many Faces of Multi-level Issues: Research in Multi-Level Issues, (Vol. 1, pp.255 - 270). Emerald Group Publishing Limited.

Dulebohn, J. H. (1997). Social influence in justice evaluations of human resource systems. In: Ferris, G. R. (Ed.). Research in Personnel and Human Resource Management, (Vol. 15, pp. 241-291). Greenwich, CT: JAI Press.

Farrell, D., \& Peterson, J. C. (1982). Patterns of political behaviour in organizations. Academy of Management Review, 7(3), 403-412. https://doi.org/10.5465/amr.1982.4285337

Fedor, D. B., \& Maslyn, J. M. (2002). Politics and political behavior: Where else do we go from here? In Francis J. Yammarino, Fred Dansereau (ed.) The many faces of multi-level issues:Research in MultiLevel Issues (Vol. 1, pp. 271 - 285). Emerald Group Publishing Limited.

Ferris, G. R., \& Treadway, D. C. (2012). Organizational politics: History, construct specification, and research directions. In G. R. Ferris, \& D. C. Treadway (Eds.), Politics in organizations: Theory and research considerations (pp. 1-24). New York: Routledge/Taylor and Francis.

Ferris, G. R., Frink, D. D., Galang, M. C., Zhou, J., Kacmar, K. M., \& Howard, J. L. (1996) Perceptions of organizational politics: Prediction, stress-related implications, and outcomes. Human Relations, 49, 233-266.

Ferris, G. R., Adams, G. , Kolodinsky, R. W., Hochwarter, W. A., Ammeter, A. P. (2002), Perceptions of 
organizational politics: Theory and research directions, in Francis Yammarino, Fred Dansereau (ed.) The many faces of multi-level issues: Research in Multi-Level Issues, (Vol. 1, pp.179 - 254). Emerald Group Publishing Limited.

Ferris, G., Russ, G., \& Fandt, P. (1989). Politics in organizations. In R. Giacalone \& P. Rosenfeld (Eds.). Impression management in the organization (pp. 143-170). Hillsdale, NJ: Lawrence Erlbaum.

Ferris, G. R., Harrell-Cook, G., \& Dulebohn, J. H. (2000). Organizational politics: The nature of the relationship between politics perceptions and political behavior, in (ed.) Research in the Sociology of Organizations: Research in the Sociology of Organizations, (Vol. 17, pp. 89-130). Emerald Group Publishing Limited,

Gandz, J., \& Murray, V. (1980). The experience of workplace politics. Academy of Management Journal, 23(2), 237-251. https://doi.org/10.5465/255429

Gaskin, J. \& Lim, J. (2016). Model fit measures: AMOS plugin. Gaskination's statwiki. Retrieved from http://statwiki.kolobkreations.com/index.php?title=Plugins

Hair, J., Black, W., Babin, B., \& Anderson, R. (2010). Multivariate data analysis (7th ed.). Upper Saddle River, NJ, USA: Prentice-Hall, Inc.

Harrell-Cook, G., Ferris, G. R., \& Dulebohn, J. H. (1999). Political behaviors as moderators of the perceptions of organizational politics-work outcomes relationships. Journal of Organizational Behavior, 20, 1093-1105. https://doi.org/10.1002/(SICI)1099-1379(199912)20:7\%3C1093::AIDJOB945\%3E3.0.CO;2-\%23

Harris, K., \& Kacmar, M. K. (2005). Organizational politics. In J. Barling, E. K. Kelloway \& M. R. Frone (eds), Handbook of work stress (pp. 353-74). Thousand Oaks, CA: Sage.

Hill, S. E., Thomas, A. L. E., \& Meriac, J. P. (2016). Political behaviors, politics perceptions and work outcomes: Moving to an experimental study. In E. Vigoda-Gadot and A. Drory (Eds.), Handbook of organizational politics: Looking back and the future (pp. 369-400) .Cheltenham: Edward Elgar publishing.

Hochwarter, W. (2003). The interactive effects of pro-political behavior and politics perceptions on job satisfaction and affective commitment. Journal of Applied Social Psychology, 33, 1360-1378. https:// doi.org/10.1111/j.1559-1816.2003.tb01953.x

Hu, L.T., \& Bentler, P. M. (1999). Cutoff criteria for fit indexes in covariance structure analysis: Conventional criteria versus new alternatives. Structural Equation Modeling, 6(1), 1-55. https://doi. org/10.1080/10705519909540118

Kacmar, K. M., \& Ferris, G. R. (1991). Perceptions of organizational politics scale (POPS): Development and construct validation. Educational and Psychological Measurement, 51,193-205. https://doi. org/10.1177\%2F0013164491511019

Landells, E. M., \& Albrecht, S. L. (2016). Organizational politics and maturity model: an integration and extension of existing models and dimensions. In E. Vigoda-Gadot \& A. Drory (Eds.), Handbook of organizational politics: Looking back and the future (pp. 295-318). Cheltenham, UK: Edward Elgar.

Leslie, L. M., \& Gelfand, M. J. (2012). The cultural psychology of social influence: Implications for organizational politics. In G. R. Ferris \& D. C. Treadway (Eds.), SIOP organizational frontiers series. Politics in organizations: Theory and research considerations (p. 411-447). Routledge/Taylor \& Francis Group.

Malhotra N. K., Dash S. (2011). Marketing research and applied orientation. London: Pearson Publishing. Maslyn, J., \& Fedor, D. B. (1998). Perceptions of politics: Does measuring different foci matter? Journal of Applied Psychology, 84, 645-653. https://doi.org/10.1037/0021-9010.83.4.645

Mayes, B. T., \& Allen, R. W. (1977). Toward a definition of organizational politics. Academy of Management Review, 2, 672-677. https://doi.org/10.5465/amr.1977.4406753

Mintzberg, H. (1983). Power in and around organizations. Englewood Cliffs, NJ: Prentice Hall.

Perrewé , P. L., Ferris, G. R., Frink, D. D., \& Anthony, W. P. (2000). Political skill: An antidote for 
workplace stressors. Academy of Management Executive, 14, 115-123. https://doi.org/10.5465/ ame.2000.4468071

Peterson, R. A., \& Kim, Y. (2013). On the relationship between coefficient alpha and composite reliability. Journal of Applied Psychology, 98(1), 194-198. https://doi.org/10.1037/a0030767

Pfeffer, J. (1981). Power in organizations. Boston: Pitman.

Sederberg, P. C. (1984). The politics of meaning: Power and explanation in the construction of social reality. Tucson, AZ: University of Arizona Press.

Valle, M. (1997). Perceptions of organizational politics and subsequent behaviors. Psychological Reports, 81(3), 945-1006. https://doi.org/10.2466\%2Fpr0.1997.81.3.945

Valle, M., \& Perrewe, P. (2000). Do politics perceptions relate to political behaviors? Human Relations, 53(3), 359-386. https://doi.org/10.1177\%2F0018726700533004

Vigoda, E. G. (2003). Developments in organizational politics. Cheltenham: Edward Elgar Publishing.

Vigoda, E., \& Cohen, A. (2002). Influence tactics and perceptions of organizational politics: A longitudinal study. Journal of Business Research, 55(4), 311-324. https://doi.org/10.1016/S0148-2963(00)00134-X

Wayne, S. J., \& Ferris, G. R. (1990). Influence tactics, affect, and exchange quality in supervisor-subordinate interactions: A laboratory experiment and field study. Journal of Applied Psychology, 75(5), 487-499. https://doi.org/10.1037/0021-9010.75.5.487 